\title{
Immunohistochemical Predictors of Bone Metastases in Breast Cancer Patients
}

\author{
Piotr Winczura $^{1,6}$ - Katarzyna Sosińska-Mielcarek ${ }^{2} \cdot$ Renata Duchnowska ${ }^{4}$. \\ Andrzej Badzio ${ }^{1,6}$ • Joanna Lakomy ${ }^{1}$ Hanna Majewska ${ }^{1}$ - Rafal Pęsaa ${ }^{1}$. \\ Beata Pieczyńska $^{1}$ - Barbara Radecka $^{3}$ - Sylwia Dębska-Szmich ${ }^{5}$. \\ Krzysztof Adamowicz ${ }^{2}$ - Wojciech Biernat ${ }^{1}$. Jacek Jassem ${ }^{1}$
}

Received: 16 February 2015 / Accepted: 26 May 2015 /Published online: 11 June 2015

(C) The Author(s) 2015. This article is published with open access at Springerlink.com

\begin{abstract}
Bones are the most common metastatic site of relapse in breast cancer patients and the prediction of bone metastases (BM) risk might prompt developing preventive and therapeutic strategies. The aim of the study was to correlate imumohistochemical (IHC) expression of selected proteins in primary breast cancer with the occurrence of BM. We analyzed expression of proteins potentially associated with BM in primary tumors of 184 patients with metastatic breast cancer (113 with- and 71 without BM). Expression of estrogen receptor (ER) in primary tumor was more common in patients with- compared to those without BM (74 vs. $45 \%$ respectively, $p=0.0001$ ), whereas in this subset less common was expression of parathyroid hormone related protein receptor type 1 (16 vs. $34 \%$, respectively, $p=0.007$ ) and cytoplasmic expression of osteopontin (OPNcyt; 1.9 vs. $14 \%$, respectively, $p=0.002$ ). The relationship between expression of ER and OPNcyt and the occurrence of BM was confirmed in the multivariate analysis. The ER-positive/OPNcyt negative phenotype was significantly more common in patients with- compared to those without BM (75 and $25 \%, p<0.0001$,
\end{abstract}

Some parts of this work have been presented at the 2012 San Antonio Breast Cancer Symposium.

Piotr Winczura

pwinczura@gmail.com

\footnotetext{
Medical University of Gdańsk, Gdańsk, Poland

Regional Oncology Center, Gdańsk, Poland

Regional Oncology Center, Opole, Poland

4 Military Institute of Medicine, Warsaw, Poland

5 Medical University of Łódź, Łódź, Poland

6 Radiotherapy Center Elblag, ul. Królewiecka 146, 82-300 Elblag, Poland
}

respectively; HR 1.79, $p=0.013$ ). Luminal A (43 vs. $23 \%$ respectively, $p=0.009$ ) and luminal $\mathrm{B} / \mathrm{HER} 2-$ positive (16 vs. $4.9 \%$ respectively, $p=0.032$ ) subtypes were more common in patients with- compared to those without BM, whereas triple negative breast cancer subtype was less common (16 vs. $38 \%$, $p=0.002$ ).

Keywords Breast cancer · Bone metastases $\cdot$ Predictive factors $\cdot$ Immunohistochemistry

\section{Introduction}

Despite continuous progress in locoregional and systemic therapies, substantial number of breast cancer patients experience relapse. Bones constitute the most common metastatic site in advanced breast cancer, with the occurrence of up to $80 \%$ [1, 2]. Patients with bone metastases (BM) have better prognosis than those with visceral involvement, and some may achieve long term survival. On the other hand, BM, due to pain and pathological fractures, significantly affect quality of life and remain a clinical challenge [1-3]. The development of BM in breast cancer is a complex phenomenon and includes dynamic interaction between malignant cells and bone tissue [4]. BM are typical for hormone receptor positive breast cancers [5-7] Results of randomized studies using adjuvant bisphosphonates to prevent $\mathrm{BM}$ in unselected groups of breast cancer patients have been inconsistent [8,9]. Molecular markers facilitating individual risk assessment of BM might be therefore clinically useful.

The aim of our study was to correlate imumohistochemical (IHC) expression of selected proteins in primary breast cancer with the occurrence of BM. The subject of this analysis were four proteins routinely determined in breast cancer patients: estrogen receptor (ER), progesterone receptor (PgR), human 
epidermal growth factor receptor 2 (HER2) and Ki67, and six investigational proteins selected by their presumed association with increased risk of BM: cyclooxygenase 2 (COX2) [10], cytokeratins 5/6 (CK5/6) [5], chemokine receptor (CXCR4) [11], parathyroid hormone related protein receptor type 1 (PTHrPR1) [12, 13], osteopontin (OPN) [14, 15] and calcium sensing receptor (CaSR) [16].

\section{Materials and Methods}

\section{Patient Population}

The study was performed in 10 Polish oncology institutions and was approved by the Ethics Committee of the coordinating center, the Medical University in Gdańsk. The study group included 184 patients with metastatic breast cancer, including 113 patients with- and 71 without diagnosed BM (Table 1). The diagnosis of BM was based on specific symptoms confirmed by imaging (X-ray, CT, MRI or bone scintigraphy) or pathology. No screening for asymptomatic BM was performed. The group with BM included also other locations of metastatic disease (viscera, soft tissue). Notably, visceral metastases were present in over $90 \%$ of patients in the non-BM group. Clinical data were extracted directly from the medical charts.

\section{Preparation of the Tissue Microarrays (TMA)}

For each case, a pathologist identified representative tumor area on paraffin fixed block, using a stained hematoxylineosin section on a glass slide. From each block two tissue cores of $1.5 \mathrm{~mm}$ were taken. Manual Tissue Arrayer manufactured by Beecher Instruments (MTAI K7 Biosystems) was used for preparation of tissue microarrays.

\section{Protein Expression}

Expression of each protein was evaluated on stained $4 \mu \mathrm{m}$ sections. Characteristics of the antibodies used in the study are presented in Table 2. Primary antibodies were incubated according to manufacturer's instructions and staining was performed with the use of Novolink Polymer Detection System by Novocastra.

For ER and PgR the staining was considered positive when at least $1 \%$ of tumor nuclei expressed the proteins [17]. HER2 expression was classified as positive (3+) if strong membranous reaction was seen in more than $30 \%$ of the invasive cancer cells. In the case of equivocal staining $(2+)$ fluorescent in situ hybridization (FISH) data were taken from medical charts, and if not available, FISH was performed using TMA. FISH results were considered positive if HER2/ chromosome 17 centromere signals ratio was higher than 2.2
Table 1 Patient characteristics

\begin{tabular}{|c|c|c|c|}
\hline Variable & $\begin{array}{l}\text { Bone } \\
\text { metastases } \\
\text { group }(N=113)\end{array}$ & $\begin{array}{l}\text { Extraskeletal } \\
\text { metastases } \\
\text { group }(N=71)\end{array}$ & $\begin{array}{l}\text { Total } \\
(N=184)\end{array}$ \\
\hline Mean age (range) & $52(30-78)$ & $54(30-83)$ & $53(30-83)$ \\
\hline \multicolumn{4}{|l|}{ Menopausal status } \\
\hline - Premenopausal & $51(45 \%)$ & $26(37 \%)$ & $77(42 \%)$ \\
\hline - Postmenopausal & $62(55 \%)$ & $42(59 \%)$ & $104(57 \%)$ \\
\hline - Unknown & & $3(4.2 \%)$ & $3(1.6 \%)$ \\
\hline \multicolumn{4}{|l|}{ Histology } \\
\hline - Ductal & $88(78 \%)$ & $58(82 \%)$ & $146(79 \%)$ \\
\hline - Lobular & $18(16 \%)$ & $9(13 \%)$ & $27(15 \%)$ \\
\hline $\begin{array}{l}\text { - Mixed } \\
\quad \text { (ductal/lobular) }\end{array}$ & $3(2.7 \%)$ & $3(4.2 \%)$ & $6(3.3 \%)$ \\
\hline - Other types & $4(3.5 \%)$ & $1(1.4 \%)$ & $5(2.7 \%)$ \\
\hline \multicolumn{4}{|l|}{ Stage at diagnosis } \\
\hline$-\mathrm{I}$ & $8(7.1 \%)$ & $3(4.3 \%)$ & $11(6 \%)$ \\
\hline- II & $51(45 \%)$ & $32(45 \%)$ & $83(45 \%)$ \\
\hline - III & $40(35 \%)$ & $34(49 \%)$ & $74(41 \%)$ \\
\hline$-\mathrm{IV}$ & $14(12 \%)$ & $1(1.4 \%)$ & $15(8.2 \%)$ \\
\hline - Unknown & $0(0 \%)$ & $1(1.4 \%)$ & $1(0.5 \%)$ \\
\hline \multicolumn{4}{|l|}{ Primary surgery } \\
\hline $\begin{array}{l}\text { - Mastectomy or } \\
\text { breast conserving } \\
\text { surgery }\end{array}$ & $99(88 \%)$ & $68(96 \%)$ & $167(91 \%)$ \\
\hline - Biopsy only & $14(12 \%)$ & $3(4.2 \%)$ & $17(9.2 \%)$ \\
\hline \multicolumn{4}{|l|}{ Radiotherapy } \\
\hline - Yes & $100(89 \%)$ & $47(66 \%)$ & $147(79 \%)$ \\
\hline - No/unknown & $13(11 \%)$ & $24(34 \%)$ & $37(21 \%)$ \\
\hline \multicolumn{4}{|l|}{ Chemotherapy } \\
\hline - Yes & $102(91 \%)$ & $66(93 \%)$ & $168(91 \%)$ \\
\hline - No/unknown & $11(9.4 \%)$ & $5(6.5 \%)$ & $16(8.7 \%)$ \\
\hline \multicolumn{4}{|l|}{ Hormonal therapy } \\
\hline - Yes & $78(69 \%)$ & $39(55 \%)$ & $117(63 \%)$ \\
\hline - No/unknown & $35(31 \%)$ & $32(45 \%)$ & $67(37 \%)$ \\
\hline \multicolumn{4}{|c|}{ Dominant site of metastases ${ }^{\mathrm{a}}$} \\
\hline - Bones & $69(61 \%)$ & $0(0 \%)$ & $69(38 \%)$ \\
\hline - Viscera & $44(39 \%)$ & $65(91 \%)$ & $109(59 \%)$ \\
\hline - Soft tissues & $0(0 \%)$ & $6(8.5 \%)$ & $6(3.5 \%)$ \\
\hline
\end{tabular}

${ }^{a}$ Dominant site of metastases refers to the metastatic site with the worst prognosis

[18]. Ki67 immunostaining was considered high if $\geq 14 \%$ of the tumor nuclei stained positive $[19,20]$. CK 5/6, tumors were classified as positive if any membranous or cytoplasmic staining was present [21]. Immunostaining for COX2 was considered positive when moderate or strong cytoplasmic expression was present in $\geq 10 \%$ tumor cells [22]. CXCR4 expression was assessed separately in the nucleus $\left(\mathrm{CXCR} 4_{\mathrm{n}}\right)$ and cytoplasm $\left(\mathrm{CXCR} 4_{\text {cyt }}\right)$, and staining in $\geq 1 \%$ of the cells was considered positive [23]. CaSR was assessed in the cytoplasm [16] and immunostaining was considered positive if 
Table 2 Antibodies used in the study

\begin{tabular}{|c|c|c|c|c|c|}
\hline Protein & Manufacturer & Antigen retrieval & Incubation time & Dilution & Method of evaluation \\
\hline ER & Novocastra,NCL-L-ER-6F11 & $\mathrm{HIER}^{\mathrm{a}}(\mathrm{ph} 6)$ & $1.5 \mathrm{~h}$ & $1 / 400$ & Semi-quantitative \\
\hline $\mathrm{PgR}$ & Novocastra,NCL-L-PGR-312 & HIER (ph6) & $1.5 \mathrm{~h}$ & $1 / 400$ & Semi-quantitative \\
\hline HER2 & Novocastra,NCL-L-CB11 & HIER (ph9) & $1.5 \mathrm{~h}$ & $1 / 50$ & Semi-quantitative \\
\hline Ki 67 & Novocastra, NCL-L-Ki67-MM1 & HIER (ph6) & $1.5 \mathrm{~h}$ & $1 / 1200$ & Semi-quantitative \\
\hline OPN & Abcam, ab 33046 & HIER (ph6) & $1.5 \mathrm{~h}$ & $1 / 200$ & Semi-quantitative \\
\hline CXCR4 & Invitrogen, 358800 & HIER (ph6) & $1.5 \mathrm{~h}$ & $1 / 25$ & Semi-quantitative \\
\hline CaSR & Pierce Bio., PA1-37213 & HIER (ph6) & $1.5 \mathrm{~h}$ & $1 / 50$ & Semi-quantitative \\
\hline $\mathrm{COX} 2$ & Abcam, ab 10940 & HIER (ph6) & $1.5 \mathrm{~h}$ & $1 / 100$ & Semi-quantitative \\
\hline CK 5/6 & Millipore, MAB1620 & HIER (ph9) & $1.5 \mathrm{~h}$ & $1 / 400$ & Qualitative \\
\hline PTHrPR1 & Abcam, ab 3271 & HIER (ph6) & $1.5 \mathrm{~h}$ & $1 / 50$ & Semi-quantitative \\
\hline
\end{tabular}

${ }^{\mathrm{a}}$ HIER - heat induced epitope retrieval (in pressure cooker under $120 \mathrm{hPa}$ for $2.5 \mathrm{~min}$ )

moderate to strong reaction was seen in $\geq 50 \%$ of cancer cells. For OPN and PTHrPR1 both cytoplasmic intensity (0 - no staining, 1 - weak, 2 - moderate, 3 - strong) and percent of stained cells ( 1 for $\leq 1 \%, 2$ for $>1-10 \%, 3$ for $>10-33 \%, 4$ for $>33-66 \%, 5$ for $>66 \%$ ) were assessed and summarized, analogous to Allred score used for ER and PgR assessment. The cutoff values for PTHrPR1 and $\mathrm{OPN}_{\text {cyt }}$ were optimized at $>6$ and $>7$, respectively, to maximize the hazard risk of bone relapse between patients with expression levels above vs. below the cutoff. For OPN the nuclear expression was additionally assessed, and staining in $\geq 50 \%$ of the cells was considered positive. Positive staining examples of $\mathrm{CK} 5 / 6, \mathrm{COX} 2$, OPN, PTHrPR1, CaSR and CXCR4 are shown in Fig. 1.

Based on the expression of ER, PgR, HER2 and Ki67, five main breast cancer phenotypes were distinguished [19]. ERand/or PgR-positive, HER2-negative and Ki67-low tumors were classified as luminal A, ER- and/or PgR-positive, HER2-negative and Ki67 high - as luminal B/HER2-negative, ER- and/or PgR-positive and HER2-positive - as luminal B/HER2-positive, ER/PgR-negative and HER2-positive - as nonluminal/HER2-positive, and ER-and/or PgR-negative and HER2-negative - as triple negative.

\section{Statistical Methods}

STATA 8.0 software was used for statistical analyses. Categorical variables were compared using two-sided Pearson's chi-square test, and for small group samples Fisher exact test was applied. Overall survival was estimated as time from initial pathological diagnosis to death and time to BM was the time from initial pathological diagnosis to confirmation of BM either with imaging or pathological examination. Overall survival and time to BM were calculated using Kaplan-Meier method and differences were analyzed with log-rank test. Statistical significance was considered at $p<0.05$. To evaluate the risk of BM, Cox proportional hazards regression was used.

\section{Results}

Median survival in the entire group was 48 months; 56 and 37 months in patients with- and without BM, respectively (log-rank; $p=0.0098$, Fig. 2).

ER expression in primary tumor was present in 74 and $45 \%$ of patients with- and without $\mathrm{BM}$, respectively ( $p=$ 0.0001 ; Table 3$)$. The respective figures for $\mathrm{PgR}$ were 55 and $42 \%(p=0.096)$. There were no significant differences in the occurrence of HER 2 positivity $(p=0.252)$ and high Ki67 expression between both groups $(p=0.13)$. CaSR was overexpressed in most of the analyzed specimens; in 93 and $84 \%$ of patients with- and without BM respectively ( $p=$ 0.053). OPN $\mathrm{OPt}_{\text {cyt }}$ expression was less common in patients with- compared to those without BM (1.9 and $14 \%$, respectively, $p=0.002)$, whereas nuclear OPN $\left(\mathrm{OPN}_{n}\right)$ expression did not differ significantly between both groups (37 and $48 \%$, respectively, $p=0.128$ ). PTHrPR1 overexpression was around twice less common in patients with-compared to those without BM (16 and $34 \%$, respectively, $p=0.007$ ). COX2 expression was a common occurrence in both groups (88 and $79 \%$ in patients with- and without BM, respectively, $p=0.148) . \mathrm{CXCR}_{\text {cyt }}$ was found in 87 and $90 \%$ of patients with- and without BM, respectively $(p=0.74)$, and nuclear CXCR $4_{\mathrm{n}}$ - in 64 and $66 \%$, respectively $(p=0.92)$. Expression of CK 5/6 was more common in triple negative breast cancer subtype compared to all other subtypes combined (45 and $12 \%$, respectively, $p=0.0001)$ and slightly less common in subjects with- compared to those without BM (18 and $30 \%$, respectively; $p=0.066$ ).

Multivariate analysis included proteins found to be significant (ER, PTHrPR1, OPN $\mathrm{cyt}_{\text {c }}$ ) or of borderline significance (CaSR and CK5/6) in univariate analysis. Of those, conserved ER and absent $\mathrm{OPN}_{\text {cyt }}$ proved to be independently associated with the increased occurrence of $\operatorname{BM}(p=0.002$ and $p=0.018$, respectively). 
Fig. 1 Representative images of particular proteins' expression (magnification $\times 200$ ). a CK 5/6, b CXCR4, c CaSR, d COX2, e $\mathrm{OPN}_{\mathrm{n}}, \mathbf{f} \mathrm{OPN}_{\mathrm{cyt}}, \mathbf{g} \mathrm{PTHrPR} 1$
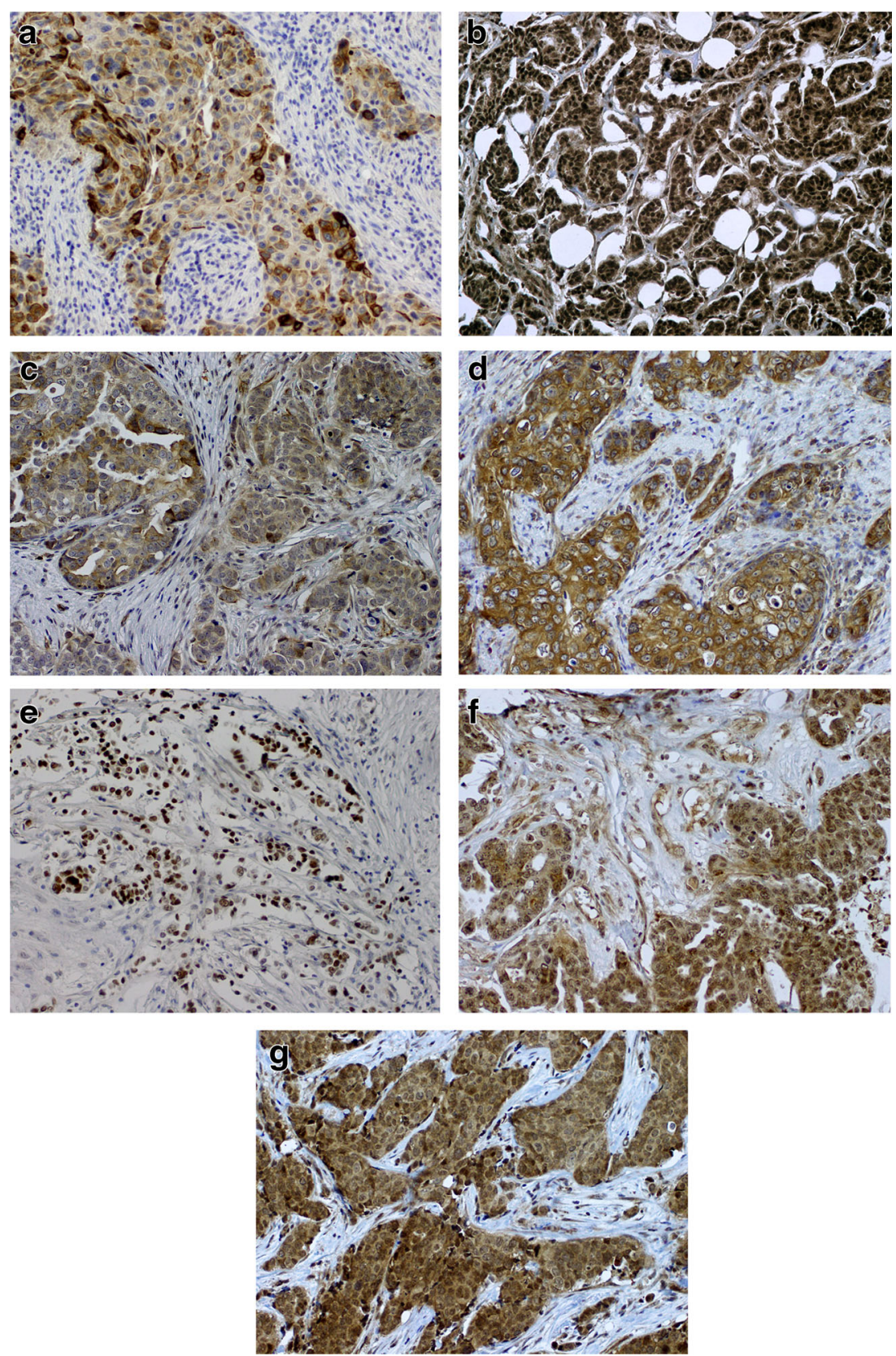

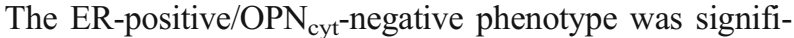
cantly more common in BM compared to non-BM group (75 and $25 \%, p<0.0001$, respectively; HR 1.79 [95\% CI $1.09-2.72]$; $p=0.013$, Fig. 3).

Intrinsic molecular breast cancer surrogates could be determined in 160 subjects ( $87 \%$; Table 4$)$. In the BM group the most common subtype was luminal A (43\%), compared to $23 \%$ in the non-BM group $(p=0.009)$. Luminal B/HER2negative subtype constituted 15 and $21 \%$ of cases in both groups, respectively ( $p=0.32$ ), and luminal B/HER2-positive subtype -16 and $4.9 \%$, respectively $(p=0.032)$. There was no significant difference in the occurrence of nonluminal/HER2- positive subtype between both study groups (9.1 vs. $13 \%$, respectively, $p=0.42$ ). Triple negative subtype was less common among patients with- compared to those without BM (16 and $38 \%$, respectively, $p=0.002$ ).

\section{Discussion}

Numerous studies investigated the predictive role of potential novel biomarkers of BM in breast cancer, but their clinical utility has not been established [12, 24, 25]. Our study showed that expression of three proteins: $\mathrm{ER}, \mathrm{OPN}_{\mathrm{cyt}}$ and PTHrPR1 in 
Fig. 2 Overall survival of patients with bone metastases $(n=113)$ and with extraskeletal metastases $(n=71)$

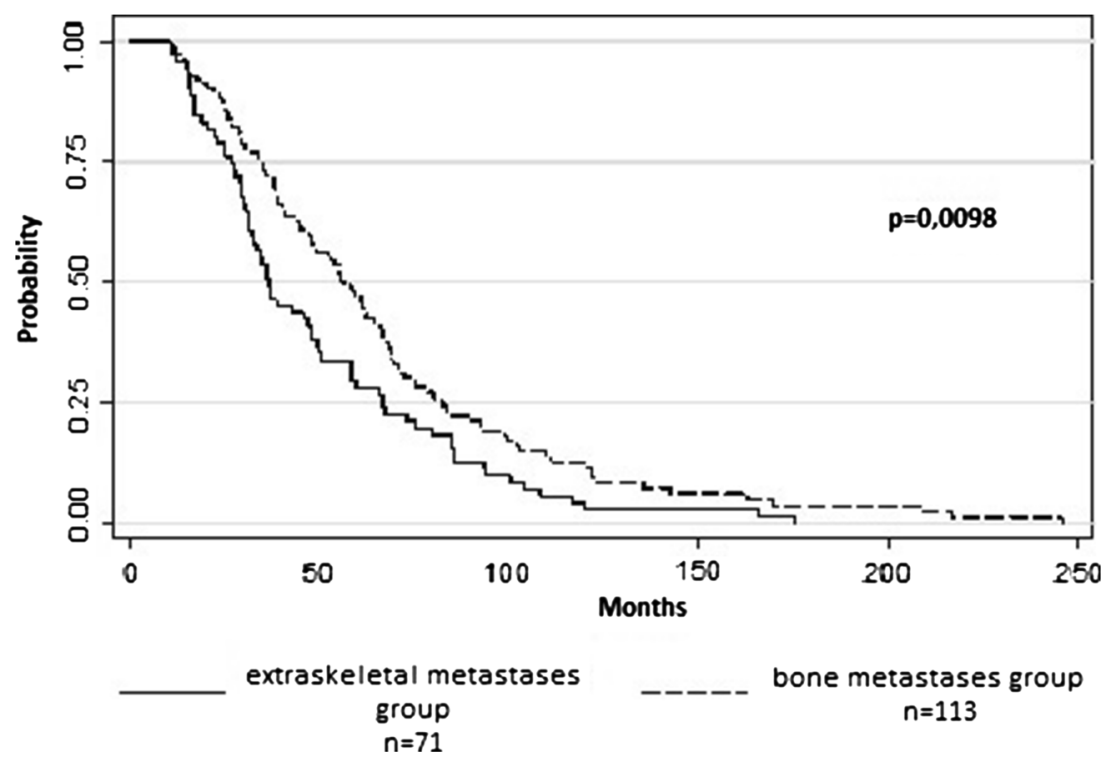

primary breast cancers may be associated with increased risk of BM. We also confirmed apparently different occurrence of BM in particular intrinsic breast cancer surrogates. In concordance with other studies [6, 7], ER positivity was associated with relatively high occurrence and increased risk of BM. For PgR the trend was similar, but the difference did not reach statistical significance. The data on the association between PgR positivity and the occurrence of BM are inconsistent [7].

In our study CaSR was expressed in the vast majority of patients and trended to be more pronounced in patients with BM. Preclinical data suggest that CaSR stimulation can trigger synthesis and secretion of PTHrP through EGFR pathway [26]. PTHrP is also a key player in pathogenesis of

Table 3 Expression of particular proteins in patients with- and without $\mathrm{BM}$ (univariate analysis; significant $\mathrm{p}$ values marked in bold)

\begin{tabular}{llll}
\hline Protein & $\begin{array}{l}\text { Bone metastases } \\
\text { group (\%) }\end{array}$ & $\begin{array}{l}\text { Extraskeletal metastases } \\
\text { group n (\%) }\end{array}$ & $p$ value \\
\hline ER & $83(74)$ & $32(45)$ & $\mathbf{0 . 0 0 0 1}$ \\
PgR & $62(55)$ & $29(42)$ & 0.096 \\
HER2 & $25(24)$ & $11(16)$ & 0.252 \\
Ki 67 & $36(37)$ & $31(49)$ & 0.13 \\
CaSR & $95(93)$ & $57(84)$ & 0.053 \\
OPN $_{n}$ & $38(37)$ & $31(48)$ & 0.128 \\
OPN $_{\text {cyt }}$ & $2(1.9)$ & $9(14)$ & $\mathbf{0 . 0 0 2}$ \\
CXCR4 $_{\text {cyt }}$ & $91(87)$ & $60(90)$ & 0.74 \\
CXCR4 $_{n}$ & $67(64)$ & $44(66)$ & 0.92 \\
PTHrPR1 & $16(16)$ & $22(34)$ & $\mathbf{0 . 0 0 7}$ \\
COX2 & $80(79)$ & $58(88)$ & 0.148 \\
CK 5/6 & $19(18)$ & $21(30)$ & 0.066 \\
\hline
\end{tabular}

osteolytic metastases. Clinical data on the role of CaSR in the development of BM in breast cancer patients are scarce, however similar results were published by Mihai et al. [16]. Despite some differences between both studies, they provide a strong signal of potential CaSR role in pathogenesis of BM.

We hypothesized that high occurrence of BM might also be associated with expression of $\mathrm{OPN}_{\mathrm{cyt}}$. OPN promotes osteolysis by enabling adhesion of osteoclasts to the bone matrix, and stimulates angiogenesis [14]. Animal studies suggested that breast cancer cells expressing OPN have higher prevalence to BM, particularly if they coexpress IL-11, another potent osteolytic factor [24]. Other studies showed that OPN stimulates progression of cancer and distant metastases [27], and is an adverse prognostic factor [15]. We found significantly lower occurrence of $\mathrm{OPN}_{\text {cyt }}$ in patients with BM. To our knowledge this is the first report on such relationship. However, owing to small number of cases staining for $\mathrm{OPN}_{\mathrm{cyt}}$, our results should be interpreted cautiously. Apart from cytoplasmic staining, we also demonstrated less typical nuclear expression of OPN. The biological role of such occurrence is not well understood. Some studies demonstrated increased nuclear content of this protein during cell division in $\mathrm{S}$ phase, suggesting its role as a transcriptor factor involved in cell proliferation [28].

In this series PTHrPR1 expression was less common in patients with- compared to those without BM. Physiology of PTHrPR1 is less understood than that of the corresponding peptide (PTHrP). It is possible, that auto- and/or paracrine stimulation of the receptor can lead to synthesis and secretion of PTHrP, which in turn stimulates osteolysis. As mentioned earlier, the whole process can be mediated by CaSR and EGFR. A retrospective study by Hoey et al. [13] showed that expression of PTHrPR1 is more common in BM compared to 
Fig. 3 Cumulative incidence of bone metastases in patients with ER-positive/OPN $\mathrm{Oyt}_{\text {chegative }}$ immunohistochemical signature vs. others. Excluded were 16 patients in whom the assessment of either ER or OPN staining was not possible

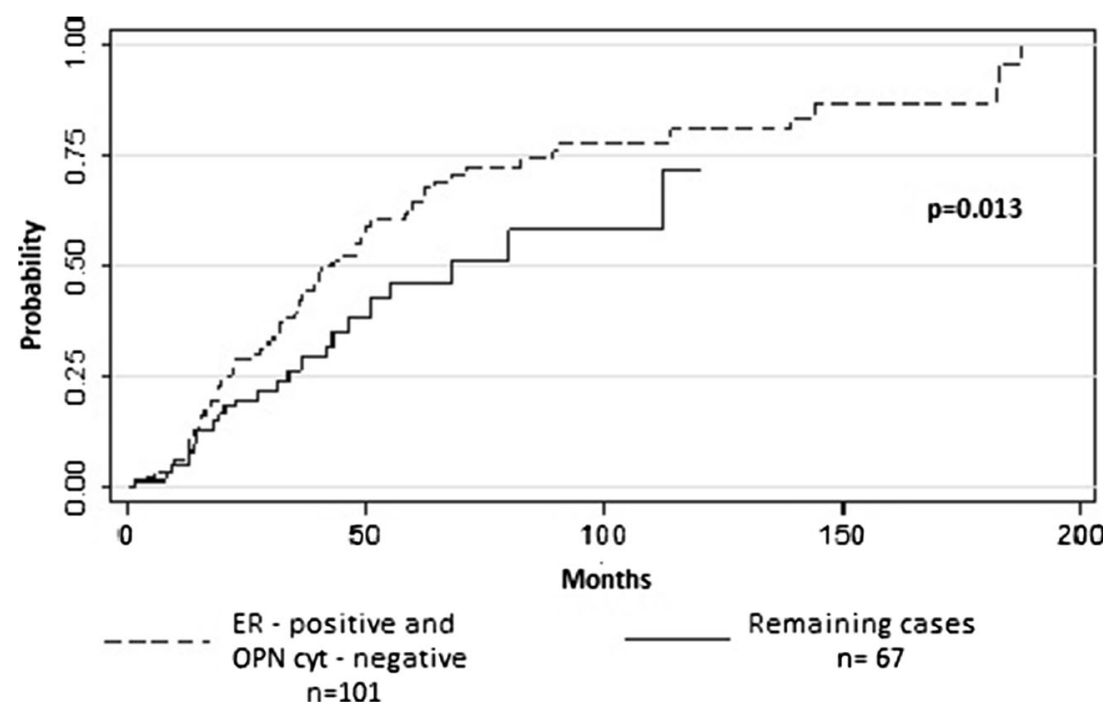

primary tumors. It was therefore postulated that expression of PTHrPR may be related to preponderance to BM. On the other hand, some data indicate that PTHrPR expression can be stimulated by the microenvironment of the metastatic cancer tissue [13]. Expression of PTHrPR in primary breast cancer was shown to be an adverse prognostic factor [12]. Indeed, PTHrPR stimulation was postulated to promote cell proliferation, invasiveness [29] and angiogenesis [30].

Taken together, OPN and PTHrPR1 play an important role in pathogenesis of BM in breast cancer patients but they are also potent molecular factors involved in cancer progression per se. This could potentially explain higher occurrence of both proteins in primary tumors of patients with extraskeletal metastases, where survival was worse.

Higher occurrence of ER-positivity and $\mathrm{OPN}_{\text {cyt }}$-negativity in tumors that formed BM was confirmed in the multivariate analysis. Notably, patients with ER-positive/OPN $\mathrm{N}_{\text {cyt }}$-negative phenotype had particularly high risk of BM. If confirmed in further studies, this finding may prompt new preventive and therapeutic strategies.

Table 4 Breast cancer phenotypes in patients with - and without BM (significant $\mathrm{p}$ values marked in bold)

\begin{tabular}{llll}
\hline Phenotype & $\begin{array}{l}\text { Bone } \\
\text { metastases } \\
\text { group n (\%) }\end{array}$ & $\begin{array}{l}\text { Extraskeletal } \\
\text { metastases } \\
\text { group n (\%) }\end{array}$ & $p$ value \\
\hline Luminal A & $43(43)$ & $14(23)$ & $\mathbf{0 . 0 0 9}$ \\
Luminal B HER2 (-) & $15(15)$ & $13(21)$ & 0.32 \\
Luminal B HER2 $(+)$ & $16(16)$ & $3(4.9)$ & $\mathbf{0 . 0 3 2}$ \\
Nonluminal HER2 $(+)$ & $9(9.1)$ & $8(13)$ & 0.42 \\
Triple negative & $16(16)$ & $23(38)$ & $\mathbf{0 . 0 0 2}$ \\
\hline
\end{tabular}

Consistent with other studies [5, 7], luminal A subtype was found to be the most common phenotype in patients with BM. Additionally, also luminal B/HER2-positive subtype was more common in the BM group. Kennecke et al. [5] estimated that the 15-year cumulative risk of BM in this latter subtype is around $30 \%$, i.e., higher than in triple negative and luminal $\mathrm{A}$ subtypes (16 and $18 \%$, respectively). Our results should be treated with caution however, given a small number of luminal B/HER2-positive cases. As expected, the extraskeletal metastases (mostly visceral) were most common in the triple negative subset of patients.

\section{Conclusion}

Our study showed that ER expression and the absence of $\mathrm{OPN}_{\text {cyt }}$ expression are strong and independent factors predicting increased risk of BM in breast cancer patients. Additionally, BM occurrence was specifically associated with luminal A and luminal/B HER2-positive subtypes.

We are aware that our study has several limitations. The methods of IHC staining for investigational proteins may be subjective, vary between particular studies and are not standardized. For most of the proteins we used previously developed scoring systems. The exceptions were CaSR and PTHrPR1, for which we constructed our own scoring systems, partially based on available literature. The obvious limitation of our study is its retrospective nature. In consequence, the non-BM group might have included patients with clinically occult BM, missed in routine management. Further, BM diagnosis was determined using diagnostic methods with different sensitivity (X-ray, CT, MRI, bone scintigraphy). Hence, independent validation of our results is warranted to consider their potential clinical relevance. 
Acknowledgments The authors would like to thank Dr J. Żok, Dr M. Strzelecka, Dr M. Kulma-Kreft, Dr M.M. Litwiniuk, Dr E. Jesień-Lewandowicz, Dr T. Rutkowski, Dr M. Jaworska-Jankowska and Dr M. Foszczyńska-Kłoda for providing tumor samples for the study.

Funding This work was supported by a research grant from the Polish Ministry of Science and Higher Education 2881/B/P01/2009/36.

Conflict of Interest The authors declare no conflict of interest.

Open Access This article is distributed under the terms of the Creative Commons Attribution 4.0 International License (http:// creativecommons.org/licenses/by/4.0/), which permits unrestricted use, distribution, and reproduction in any medium, provided you give appropriate credit to the original author(s) and the source, provide a link to the Creative Commons license, and indicate if changes were made.

\section{References}

1. Tubiana-Hulin M (1991) Incidence prevalence and distribution of bone metastases. Bone (Suppl. 1):9-10

2. Coleman RE, Smith P, Rubens RD (1998) Clinical course and prognostic factors following bone recurrence from breast cancer. Br J Cancer 77:336-340

3. Plunkett TA, Smith P, Rubens RD (2000) Risk of complications from bone metastases in breast cancer. Implications for management. Eur J Cancer 36:476-482

4. Guise TA, Mohammad KS, Clines G, Stebbins EG, Wong DH, Higgins LS et al (2006) Basic mechanisms responsible for osteolytic and osteoblastic bone metastases. Clin Cancer Res 12: 6213-6216

5. Kennecke H, Yerushalmi R, Woods R, Cheang MC, Voduc D, Speers CH et al (2010) Metastatic behavior of breast cancer subtypes. J Clin Oncol 28:3271-3277

6. Hess KR, Pusztai L, Buzdar AU, Hortobagyi GN (2003) Estrogen receptors and distinct patterns of breast cancer relapse. Breast Cancer Res Treat 78:105-118

7. Sihto H, Lundin J, Lundin M, Lehtimäki T, Ristimäki A, Holli K et al (2011) Breast cancer biological subtypes and protein expression predict for the preferential distant metastasis sites: a nationwide cohort study. Breast Cancer Res 13:R87

8. Gnant M, Mlineritsch B, Stoeger H, Luschin-Ebengreuth G, Heck D, Menzel C et al (2011) Adjuvant endocrine therapy plus zoledronic acid in premenopausal women with earlystage breast cancer: 62-month follow-up from the ABCSG12 randomised trial. Austrian Breast and Colorectal Cancer Study Group, Vienna, Austria. Lancet Oncol 12:631-641

9. Coleman RE, Marshall H, Cameron D, Dodwell D, Burkinshaw R, Keane M et al (2011) Breast cancer adjuvant therapy with zoledronic acid. N Engl J Med 365:1396-1405

10. Singh B, Berry JA, Shoher A, Lucci A (2006) COX-2 induces IL11 production in human breast cancer cells. J Surg Res 131:267275

11. Andre F, Xia W, Conforti R, Wei Y, Boulet T, Tomasic G et al (2009) CXCR4 expression in early breast cancer and risk of distant recurrence. Oncologist 14:1182-1188

12. Linforth R, Anderson N, Hoey R, Nolan T, Downey S, Brady G et al (2002) Coexpression of parathyroid hormone related protein and its receptor in early breast cancer predicts poor patient survival. Clin Cancer Res 8:3172-3177

13. Hoey RP, Sanderson C, Iddon J, Brady G, Bundred NJ, Anderson NG (2003) The parathyroid hormone-related protein receptor is expressed in breast cancer bone metastases and promotes autocrine proliferation in breast carcinoma cells. Br J Cancer 88:567-573

14. Asou Y, Rittling SR, Yoshitake H, Tsuji K, Shinomiya K, Nifuji A et al (2001) Osteopontin facilitates angiogenesis, accumulation of osteoclasts, and resorption in ectopic bone. Endocrinology 142: $1325-1332$

15. Patani N, Jouhra F, Jiang W, Mokbel K (2008) Osteopontin expression profiles predict pathological and clinical outcome in breast cancer. Anticancer Res 28:4105-4110

16. Mihai R, Stevens J, McKinney C, Ibrahim NB (2006) Expression of the calcium receptor in human breast cancer - a potential new marker predicting the risk of bone metastases. Eur J Surg Oncol 32:511-515

17. Hammond ME, Hayes DF, Dowsett M, Allred DC, Hagerty KL, Badve S et al (2010) American Society of Clinical Oncology/ College of American Pathologists guideline recommendations for immunohistochemical testing of estrogen and progesterone receptors in breast cancer (unabridged version). American Society of Clinical Oncology; College of American Pathologists. Arch Pathol Lab Med 134:48-72

18. Wolff AC, Hammond ME, Schwartz JN, Hagerty KL, Allred DC, Cote RJ et al (2007) American Society of Clinical Oncology/College of American Pathologists guideline recommendations for human epidermal growth factor receptor 2 testing in breast cancer. American Society of Clinical Oncology/ College of American Pathologists. Arch Pathol Lab Med 131: $18-43$

19. Goldhirsch A, Wood WC, Coates AS, Gelber RD, Thürlimann B, Senn HJ et al (2011) Strategies for subtypes - dealing with the diversity of breast cancer: highlights of the St. Gallen International Expert Consensus on the Primary Therapy of Early Breast Cancer 2011. Ann Oncol 22:1736-1747

20. Dowsett M, Nielsen TO, A'Hern R, Bartlett J, Coombes RC, Cuzick J et al (2011) Assessment of Ki67 in breast cancer: recommendations from the International Ki67 in Breast Cancer working group. International Ki-67 in Breast Cancer Working Group. J Natl Cancer Inst 103:1656-1664

21. Diallo-Danebrock R, Ting E, Gluz O, Herr A, Mohrmann S, Geddert $\mathrm{H}$ et al (2007) Protein expression profiling in highrisk breast cancer patients treated with high-dose or conventional dose-dense chemotherapy. Clin Cancer Res 13:488497

22. Ristimäki A, Sivula A, Lundin J, Lundin M, Salminen T, Haglund $\mathrm{C}$ et al (2002) Prognostic significance of elevated cyclooxygenase-2 expression in breast cancer. J Cancer Res 62:632-635

23. Yasuoka H, Tsujimoto M, Yoshidome K, Nakahara M, Kodama R, Sanke T et al (2008) Cytoplasmic CXCR4 expression in breast cancer: induction by nitric oxide and correlation with lymph node metastasis and poor prognosis. BMC Cancer 8:340

24. Kang Y, Siegel PM, Shu W, Drobnjak M, Kakonen SM, Cordón-Cardo C et al (2003) A multigenic program mediating breast cancer metastasis to bone. Cancer Cell 3:537-549

25. Ibrahim T, Sacanna E, Gaudio M, Mercatali L, Scarpi E, Zoli W et al (2011) Role of RANK, RANKL, OPG, and CXCR4 tissue markers in predicting bone metastases in breast cancer patients. Clin Breast Cancer 11:369-375

26. MacLeod RJ, Yano S, Chattopadhyay N (2004) Extracellular calcium-sensing receptor transactivates the epidermal growth factor receptor by a triple-membrane-spanning signaling mechanism. Biochem Biophys Res Commun 320:455-460

27. Craig AM, Bowden GT, Chambers AF, Spearman MA, Greenberg AH, Wright JA et al (1990) Secreted phosphoprotein mRNA is induced during multi-stage carcinogenesis in mouse skin and correlates with the metastatic potential of murine fibroblasts. Int $\mathbf{J}$ Cancer 46:133-137 
28. Junaid A, Moon MC, Harding GE, Zahradka P (2007) Osteopontin localizes to the nucleus of 293 cells and associates with polo-like kinase-1. Am J Physiol Cell Physiol 292:919-926

29. Luparello C, Burtis WJ, Raue F, Birch MA, Gallagher JA (1995) Parathyroid hormone-related peptide and 8701-BC breast cancer cell growth and invasion in vitro: evidence for growth-inhibiting and invasion-promoting effects. Mol Cell Endocrinol 111:225-232

30. Akino K, Ohtsuru A, Kanda K, Yasuda A, Yamamoto T, Akino Y et al (2000) Parathyroid hormone-related peptide is a potent tumor angiogenic factor. Endocrinology 141:4313-4316 